Article

\title{
The City as a Continuous Laboratory for Diversity: The Case of Geneva
}

\author{
Christophe Monnot ${ }^{1,2}$ \\ ${ }^{1}$ ISSR, University of Lausanne, 1015 Lausanne, Switzerland; E-Mail: christophe.monnot@unil.ch \\ ${ }^{2}$ Faculty of Protestant Theology, University of Strasbourg, 67084 Strasbourg, France
}

Submitted: 25 March 2020 | Accepted: 1 July 2020 | Published: 20 August 2020

\begin{abstract}
After a long period of interest of religious plurality in the nation-state, the sociology of religion, with the impulse of the sociology of migration, has turned its attention to the city. This local level allows us to understand the issues of diversity governance. This article takes advantage of the literature on the governance of migration to apply it to the governance of religious diversity. Using data from the National Congregations Study and available data on Geneva, this article will first show how past responses to the emergence of diversity determine the path for future decisions. To this top-down regulation of religion responds one or more bottom-up strategies of religious communities to find legitimacy in a constraining environment. Based on the unit of the religious community, this study on Geneva provides a historical case of the evolution of diversity. This historical perspective provides the consistency of the current governance of religious diversity, illuminating the struggle for recognition of the minority groups.
\end{abstract}

\section{Keywords}

city; Geneva; legal framework; recognition; religious community; religious diversity; super-diversity

\section{Issue}

This article is part of the issue "Religious Minorities and Struggle for Recognition" edited by Christophe Monnot (University of Lausanne, Switzerland/University of Strasbourg, France) and Solange Lefebvre (University of Montreal, Canada).

(C) 2020 by the author; licensee Cogitatio (Lisbon, Portugal). This article is licensed under a Creative Commons Attribution 4.0 International License (CC BY).

\section{Introduction}

The context of the 21st century secular society brings new challenges to the city. Secularization relegated a portion of religiosity to the background of urban issues in the latter half of the 20th century. The establishment of variegated populations with multiple origins then brought about a disturbing resurgence of religious issues due to their sheer plurality. For instance, a group of Hare Krishna or veiled women draw a sharp contrast with a historic church building in the background. Cities have become a privileged scene of diversity in Europe. A varied population-consisting of a wide range of cultural and religious minorities with diverse demands-lives with dignity in urban areas. Diversity thus becomes "superdiversity" (Vertovec, 2007), with a multiplicity of factors that affect the place and way of life of the city's inhabitants (Burchardt \& Becci, 2016).

The city continues to be a "laboratory of the social" (Park, Burgess, \& Mackenzie, 1925, p. 79) in which di- versity is now plural, signifying a diversity within the diversity, particularly with the multiplication of religious groups of traditions with very different histories, roots, and rituals. This complex diversity is described by superdiversity, a concept to be understood as the description of a multiplication of variables that affect the place and the way of life of the city's residents. As Vertovec (2007) points out, super-diversity implies a rearrangement of legal frameworks and overlapping of expectations and values within a limited space. In this context, it is hardly surprising that debates are emerging that seek to transform, adapt, or repeal laws on the recognition of various religious communities.

Verovec's (2007) impulse was followed by extensive research on migration and diversity in cities. Migration has an impact on the dimensions of policymaking and integration policies (Caponio, Scholten, \& Zapata-Barrero, 2019; Glick Schiller \& Caglar, 2010). This article will focus on the implementation of religious diversity in the city and especially the settlement of religious commu- 
nities. The aim of this article is to show, through the case of the establishment of religious groups in Geneva, how the demands for recognition of religious minorities lead to changes in the legislative framework and how religious groups adapt for their establishment to a constraining institutional and social environment. The case of Geneva is interesting because from an entirely Calvinist city, its Protestantism diversified during the 19th century. Moreover, the addition of Catholic communes to its territory when Geneva joined Switzerland in 1815 posed many problems in the governance of this new diversity. Then, in the last quarter of the 20th century, its position as an international city gave it a cosmopolitan population with the settlement of very diverse religious groups.

The article is organized as follows. Section 2 is devoted to the literature. The city and the local context present new interests for sociologists of migration but also of religion to apprehend the governance of diversity. The installation of religious groups is also a new perspective to better understand local policies and participation. In Sections 3 and 4, the case of Geneva will be presented through the lenses of the installation of the different groups using the available data from the National Congregations Survey in Switzerland (2007-2010), updated by a second census in Geneva (2014). In Section 5, the top-down management of religious diversity-that is, the different legal responses by the authorities to diversity-will be discussed. These legal responses trace an institutional path for current decisions. Section 6 will present the bottom-up management of diversity: the strategies that religious groups follow in Geneva to obtain legitimacy in a secular society. To conclude, we will underline how these two ways (top-down and bottom-up) of managing diversity are closely linked and respond to each other.

\section{City and Religious Diversity}

In the way opened by Wimmer and Glick Schiller (2002) calling for migration and diversity to be studied not only at the national level, but also at the local level, several studies have shown fruitfully the impact of local governance on migration (Duemmler \& Nagel, 2013; Glick Schiller \& Caglar, 2010). Caponio et al. (2019) identified different factors that influence local governance of migration and diversity. If the local policy on migration has been widely discussed (Caponio \& Borkert, 2010; Glick Schiller \& Caglar, 2010), and the local politics and participation as well (Joppke \& Seidle, 2012; Morales Diez de Ulzurrun \& Giugni, 2011), the history of local policy on migration and diversity is a promising direction to investigate further the local governance of migration (Hackett, 2017).

Religion in the city has already been considerably discussed. Let us quote the edited book by Berking, Steets, and Schwenk (2018) discussing the new challenge of religious plurality in the city, often considered as a secular place. The book shows how religion and the city are intertwined. Several have investigated how the set- tlement of religious groups follow different strategies or are constraints by different city governance. Becci, Burchardt, and Giorda (2016) and Burchardt, Becci, and Giorda (2018) have pointed out historically recognized or state-supported churches in cities follow a strategy of "place-keeping" in the urban environment, while non-recognized communities follow a strategy of "placemaking" and those from the holistic milieu follow a strategy of "place-seeking." Historical churches keep their place in the public space, by notably offering their imposing and recognizable religious buildings for cultural events, such as concerts or exhibitions. Vásquez and Knott (2014) noted that for migrant communities, several dimensions exist in the way religious groups manage to make a place, including spatially managing differences. The groups that are 'seeking place' are collectives from the holistic milieu or new spiritualities (Heelas \& Woodhead, 2005). For their small gatherings, they make use of coffee rooms, neighborhood centers, or public parks. These collectives are outside the usual religious register in the city, while access to a religious building is one of the key factors in their long-term establishment in the city.

Martínez-Ariño (2018b) show the increase of diversity in the (historically Catholic) city of Barcelona. First a few Protestant communities were established at the end of the 19th century, then a net increase in the last quarter of the 20th century with the settlement of Pentecostal, Muslim, Buddhist, etc. communities. Becci and Hafner (2016, pp. 107-108) conducted a mapping of all the religious groups in the city of Potsdam and observed that the settlement of religious groups is related "to the urban space ranges from territoriality to deterritorialization....Religious and spiritual newcomers negotiate their presence with the religious-secular hybridity of the spatial regimes and thereby produce social innovations." Moreover, religious plurality settlement depends on local normative definitions of what is accepted or legitimate in the public sphere or not. A legal norm and a social norm co-exist and lead the governance of diversity in the city (Martínez-Ariño, 2018a). The present article intends to interrogate the increase of diversity through the settlement of religious groups. It will also question the path the city of Geneva has pursued for the governance of plurality. Following Duemmler and Nagel (2013) studying the diversity governance in Germany and Switzerland, we will look not only at the top-down approach (regulation) but also at the bottom-up approach (struggle for recognition). Only one approach is generally analyzed in the different studies on religious plurality. However, we will see that they are closely linked, that one responds to the other, they are historical co-constructions that regulate the religious diversity.

\section{A National Congregations Study}

In order to address the establishment of religious diversity, Switzerland is one of the few countries 
where a census of all religious groups is available. Whether they are parishes of historic churches, free congregations, gatherings in mosques and synagogues, or regular spiritual and religious celebrations in different places of worship (Monnot \& Stolz, 2020), these units were included in the census conducted in 2007-2008. It was the first step of a representative study of collective religion in Switzerland-the National Congregations Study (NCS) - conducted until 2010 (Stolz, Chaves, Monnot, \& Amiotte-Suchet, 2011).

Our data allows us to grasp exact information on the number and percentages of local religious groups in Switzerland and its organizational diversity. 5,734 local religious groups active in the Swiss territory were identified (Monnot, 2013a). In 2008, Switzerland counted $30.5 \%$ of Catholic communities, $19.1 \%$ of Reformed parishes, $24.8 \%$ of free Evangelical congregations, and $17 \%$ of non-Christian tradition communities (among them $5.5 \%$ are linked to Islam). Buddhists represent $2.5 \%$ of the groups, and Hindus 3.3\%. Other traditions were included like Sikhs $(0.8 \%)$, Bahá'ís $(0.7 \%)$, esoteric groups (1.1\%), Spiritualism (0,8\%), Scientology (0.5\%), and many more besides (Monnot \& Stolz, 2020, pp. 140-141). According to the updated census conducted by Knobel, Gonzales, and Montandon (2014), there are 400 religious communities in Geneva and 270 places of worship in the city.

An important result of this census shows that the diversity is located mainly in the city and urban area (Monnot \& Stolz, 2018). As Stringer (2013) points out, no matter what our theory for conceptualizing the city, it is the place of super-diversity and religion plays an important role in this context. It is therefore not surprising to observe that Swiss cities are the space of religious diversity. Figure 1 thus shows in a simplified manner this difference in the distribution of four religious categories between cities, urban area, and rural area. Cities have the most non-Christian and nonestablished religious communities as well as the highest rate of non-believers. $31 \%$ of the groups are nonChristian gatherings: Buddhists, Hindus, Jews, Muslims, and New Religious Movements. 11\% of the groups are Other Christians (e.g., Lutherans, Anglicans, messianic congregations: Jehovah's Witnesses, Latter-Day Saints, New-Apostolics, etc.) and 32\% are Evangelicals-leaving only $26 \%$ to the established Christian parishes.

This figure is similar to what we can observe in Geneva, where $84 \%$ of the communities are located in urban areas. In the rural communes of the canton, there are almost only Catholic and Protestant churches. A "rural-urban gap" is visible with a concentration of religious diversity in urban areas (Monnot \& Stolz, 2020, p. 141).

\section{Establishment of Diversity in Geneva}

The city of Geneva is of particular interest. First, the census carried out for NCS has been updated by Knobel et al. (2014). Secondly, Geneva has two historical particularities in terms of religious plurality. Following the Congress of Vienna, the city of Geneva became a Swiss canton in 1815 with the addition of a rural territory that is essentially Catholic. Having had an entirely Protestant population in the 17th century, the town was gradually confronted with religious plurality at different stages of its history. The second turning point was the installation of the European headquarters of the United Nations, followed by the establishment of numerous interna-

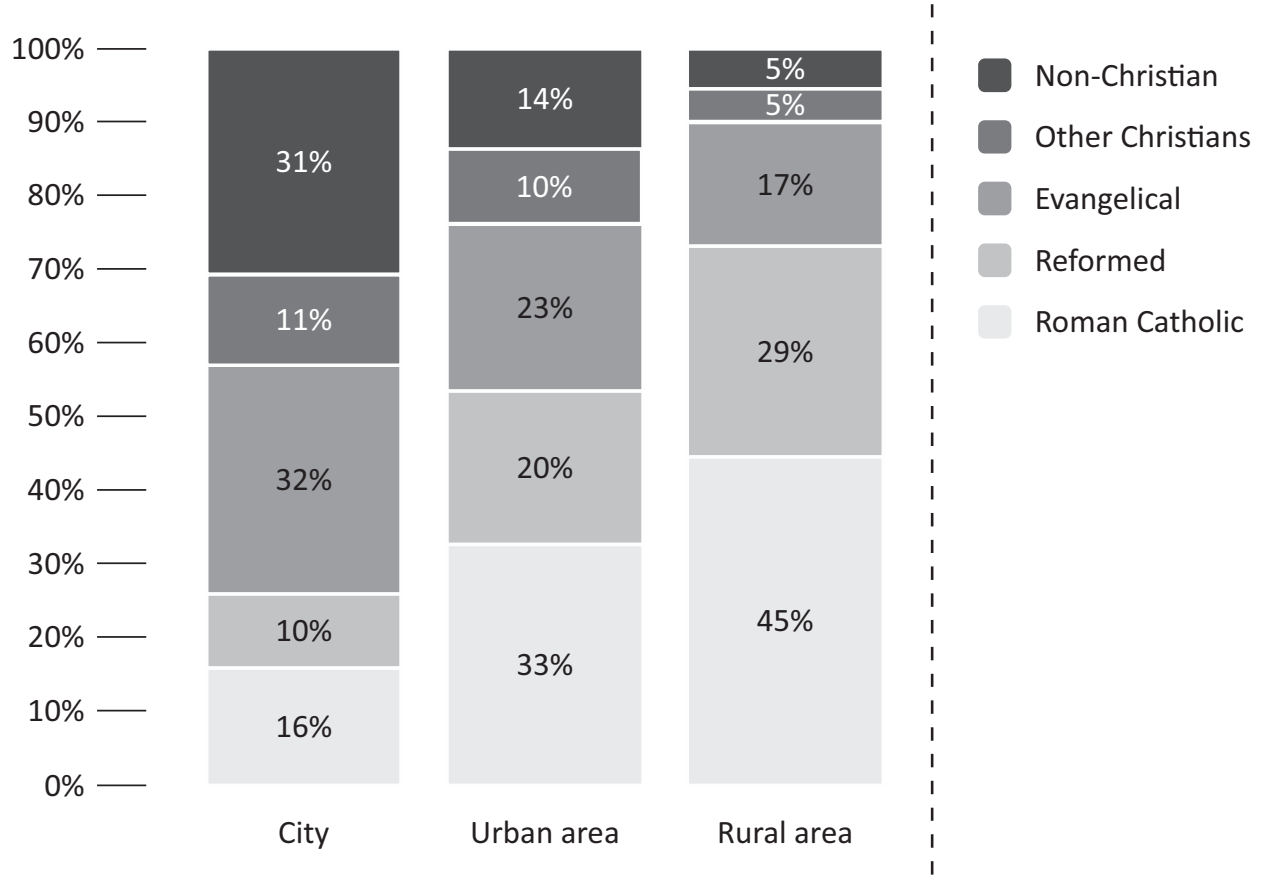

Figure 1. Division of religious traditions in Switzerland in urban and rural areas. Source: Stolz et al. (2010). 
tional organizations. Geneva has thus become a very cosmopolitan city with a population of more than $40 \%$ foreigners despite its size of a little less than 500,000 inhabitants. The process of establishing religious diversity is particularly evident in Geneva: A city that was one of the key centers for the dissemination of the Reformation is now the place for the whole range of the great religious traditions.

Geneva quickly adopted Protestantism, as did other major Swiss cities such as Zurich, Basel, Bern, and Lausanne. The process of the diversification of Protestantism began in 1766, as Table 1 shows. It was at this time that the Lutheran Church established the first non-Calvinist place of worship in the old town. The German-speaking community settled in a mansion near the cathedral in the center of the city, without adding a single religious symbol. 50 years later, the 'Revival of Geneva' (from ca. 1810 onwards; Bastian, 2016) profoundly affected the Protestant city by subdividing Protestantism into two major trends-the National Church and the Free Church. However, the few chapels initiated by the Evangelical Society, which later became the Free Church of Geneva, did not transform the architectural space in any way. The Pélisserie chapel, which was built in 1839 , and the Oratoire chapel, which was inaugurated in 1836, are recognizable as religious buildings only from an interior courtyard. Thus, at this point there had only been an internal diversification of Protestantism. It was only in the middle of the 19th century that Protestant plurality came from outside Geneva with new evangelical movements. First, with a Darbyst group in 1842, and second, with the Methodist Church in 1867, which settled about a hundred meters from the Lutheran Church. Despite the establishment of Protestant diversity (cf. Table 1), Geneva and its urban organization stayed the same, as buildings of the new congregations remained totally invisible. Indeed, in the history of Geneva, despite the schisms, the new Protestant groups did not seek to and were unable to overshadow the great temples of the historic and 'national' Protestant Church. In the mid-19th century, the ringing of the cathedral bell served as a call to worship for all Protestants, despite their division into different communities since the early 19th century pietist 'revival.'

During the second stage of diversification, religious diversity became more visible, with new claims for recognition through the settlement of diverse groups within the urban periphery. When Geneva became part of the Swiss Confederation in 1815, the Protestant citadel began to destroy its walls, opening up the city. The first

Table 1. Years of the establishment of diversity in the city of Geneva.

\begin{tabular}{|c|c|}
\hline First Religious Group & Year of Foundation \\
\hline \multicolumn{2}{|l|}{ First non-Calvinist Church } \\
\hline Lutheran Church & 1766 \\
\hline \multicolumn{2}{|l|}{ First "Evangelical Movement" } \\
\hline ‘Revival of Geneva' & $1815-1850$ \\
\hline Chapel of Oratoire & 1836 \\
\hline Chapel of Pelisserie & 1839 \\
\hline First Darbyst group & 1842 \\
\hline First Anglican Church & 1853 \\
\hline \multicolumn{2}{|l|}{ First non-Protestant Church } \\
\hline Catholic 'Cathedral' & 1857 \\
\hline \multicolumn{2}{|l|}{ First Jewish group } \\
\hline First Jewish Synagogue & 1859 \\
\hline Russian Orthodox Cathedral & 1866 \\
\hline First Methodist Church & 1867 \\
\hline First Christ Catholic Church (National Catholic) & 1873 \\
\hline \multicolumn{2}{|l|}{ First non-Christian (except Jewish) } \\
\hline First Bahá'ís group & 1948 \\
\hline First Muslim group & 1961 \\
\hline First Buddhist group & 1962 \\
\hline First Hindu group & 1962 \\
\hline First Ahamdiyya group & 1970 \\
\hline Great Mosque of Geneva & 1978 \\
\hline First Shia group & 1992 \\
\hline First Taoist group & 2006 \\
\hline First Sikh group & 2008 \\
\hline
\end{tabular}

Sources: Knobel et al. (2014) and Monnot (2013a). 
belt around the city offered opportunities to build new settlements. This allowed several non-Protestant places of worship to be built-namely the Catholic 'Cathedral,' the Russian Orthodox Cathedral, and the Synagogue. Although Geneva's neighboring communes had their own Catholic Church, the city remained overwhelmingly Protestant. However, it was not until the destruction of the ramparts that a Catholic Church could be built. In 1857, the Catholic Church inaugurated a building remarkable for its size and architectural willingness to appear equal to a cathedral, with which it ostensibly posed an architectural challenge to the Protestant cathedral (Amsler \& Scholl, 2013; Grandjean \& Scholl, 2010). A few years later, the Russian Orthodox Church was erected in 1866. At the end of its construction, it stood alone on the margins of Calvin's town. Then, little by little, important buildings surrounded it until it integrated perfectly into the city-so much so that any inhabitant of the actual city will situate it in the 'old town.' With its golden dome, the building makes a visible architectural difference in the cityscape.

A new step of diversification started when, at the end of the Second World War, Geneva took on an international dimension. Non-Christian groups began to settle in Geneva, with one of the most striking examples being the inauguration of the Grand Mosque of Geneva in 1978, located near the international organizations quarter (European Headquarters of the United Nations, World Health Organization, and World Trade Organization main buildings). It was inaugurated in the presence of the Federal Council and the Prince of Saudi Arabia. As in the 19th century, groups with distinctive buildings are being pushed out of the town center. The only opportunity to build a religious edifice is within the city's confines. In Geneva, an emblematic example is the Armenian Apostolic Church "Surp Hagop," founded in 1969. Its recognizable building is located outside the city, surrounded by trees and opulent villas, $6 \mathrm{~km}$ away from the center. Another example is the Fo Guang Shan Buddhist temple, built in 2006, also on the outskirts of the city, $1 \mathrm{~km}$ from Geneva airport. However, an important diversity has settled within the city, but invisibly. More than $60 \%$ of the communities identified in Geneva in 2013 by Knobel et al. (2014) and in 2008 by Monnot (2013a) are religious minorities. Those that have been able to settle in the center of the city have hidden spaces and Geneva currently has more than 120 spaces that have been reconverted for religious activities. These are former cinemas, craftsmen's workshops, commercial or administrative premises, post offices, restaurants, museums, or garages. Occasionally, residential areas such as apartments or individual houses were converted.

This brief historical overview of Geneva suggests the emergence of a 'new' religious diversity in the city under the influence of people who have recently settled there. The first stage, which occurred at the turn of the 19th century, witnessed the diversification of Protestantism. First, by internal movements under the in- fluence of Pietism, then by external movements-mainly British (Anglicans, Methodists). The second stage took place around 1850, when Christianity diversified. Except for the synagogue, it was almost a century later, at the end of the Second World War, that non-Christian groups began to settle.

These minorities originate mainly from demand for manpower for companies based in Geneva, multinational companies, and international organizations, but also from religious minorities oppressed in their countries, such as the Ahmadiyya of Pakistan, the Bahá'ís of Iran, and the Alevis of Turkey (Monnot, 2013b). Furthermore, groups such as the Buddhists of Tibet, the Tamils from Sri Lanka, and the Muslims from BosniaHerzegovina have also settled in Geneva due to conflict in their home countries.

\section{Diversity in Geneva: The Top-Down Management}

The history of Geneva is not only that of the diversification of religion. It is also a history of political debates on the legal framework of religion. As stated by MartinezAriño: "Cities are not only sites where religious diversity becomes more visible (Becci, Burchardt, \& Casanova, 2013; Knott, Krech, \& Meyer, 2016), but also sociospatial configurations where controversies over issues related to public expressions of religiosity take shape and are negotiated" (Martínez-Ariño, 2019, p. 364). At the turn of the 19th century, Geneva was the scene of spectacular religious changes which heckled the political life of the century until the promulgation of a law in 1907 which, in fact, separated the State from the Church.

From the 16th century with a Protestant church-city, the controversies of the 19th century pushed Geneva to become the single Swiss canton without any "national church" and to no longer support religious groups either directly or indirectly (through taxes or subsidies; Grandjean \& Scholl, 2010). In 1803, under Napoleon's occupation, the first mass was celebrated in the city of Geneva (Grandjean \& Scholl, 2010, p. 9). It prefigured the addition of Catholic territories in 1815. The new Swiss canton of Geneva known as the cradle of Calvinist Protestantism has to deal, since 1815, with a large Catholic minority. In 1822, the canton population was $38.7 \%$ Catholic (Altermatt, 1994, p. 188). The management of this increasing minority was the source of many controversies.

To add to the difficulty of managing this new Catholic minority, Protestantism-which was still in the majority-was shaken by the 'Revival of Geneva,' which began around 1810 and divided the city's Protestants into two factions (Bastian, 2016), a situation that led Geneva to have four large churches as early as 1873 . For Protestantism, a (majority) National Protestant Church and a (minority) free Church, fruit of the various waves of the 'Revival of Geneva' started at the beginning of the century. For Catholicism, a National Catholic Church made up of liberal Catholics led by democratic and local 
authorities recognized as state church in 1873 and a 'free' Roman Catholic Church, composed of the great majority of the members and clergy who remained faithful to the Roman Catholic hierarchy (Scholl, 2013).

The tensions that arose, mainly from the majority of Catholics not recognized by the Canton, were also supported by Protestants (free Church) who did not want the State to interfere in the affairs of the Church and other Protestants (National Church) who promoted free thinking. Several laws were debated, voted, and often rejected. It was finally in 1907 that the law requiring the canton to withdraw support for the churches from the budget was adopted, thus ending the crisis. De facto, Geneva would no longer support churches and there would no longer be any national churches (Scholl, 2013). It is therefore noticeable that, in Geneva, religious plurality provoked many debates between a state that wanted to control the churches and also churches reclaiming recognition due to the fact that their members represent a large minority of the population (Scholl, 2010). This "learning of religious pluralism" as Amsler and Scholl (2013) called this period ended with an egalitarian solution, since in the end no church would be included in the state budget. We note here that the State's contempt of a large part of the population by recognizing a schismatic and small local Catholic Church has provoked major controversies in Geneva. Peace has been restored by not recognizing any church. One interesting anecdotal fact to mention is that it is not so much on the grounds of equality that Protestants voted for the law withdrawing state support to the Church; it was much more because of the belief that by this removal the church would experiment spiritual renewal as Stolz (2018) and Stolz and Chaves (2017) have noted. These authors underlined that this belief was later disproved. The separation of church and state in Geneva led to a decline of churches, a decrease in membership, and an impoverishment of staff and resources.

In Geneva, the emergence of diversity led to a political crisis that divided the life of the city for almost a century. It was a top-down crisis in the management of pluralism, with, first of all, a desire to contain Catholicism, and then a desire from the State to control the bodies of the Churches. The law of separation of Church and State was enacted and approved by the majority of the population. It did not allow the Catholic minority to be recognized but neither did it allow the state to control the Church's bodies. One can therefore observe that the history of Geneva, with a Church strongly rooted in the life of the city, has led the politicians on a path of exclusion of the new diversity from public life. This exclusion will eventually lead to the exclusion of all churches from state support.

Interestingly enough, on the occasion of the adoption of a new Constitution in 2013, Geneva went one step further. Non-Christian diversity increased significantly in the last quarter of the 20th century. In response, the Canton stated in the constitution that it was a laïc (secular) republic, identical to France. The presence of sig- nificant religious diversity as well as of many people who do not belong to any church or religious group has prompted the state to strongly affirm separation between state and church. The course taken at the beginning of the 20th century was then further accentuated 100 years later by the emergence of new diversity. All the religious groups in Geneva are therefore currently associations under private law similar to any sports club, cultural organizations, or other associations, except that they cannot receive subsidies from the state or the city.

This top-down way of regulating religion has already been widely discussed in sociology of religion at the national level. Very recently, it is also beginning to be discussed at the city level, as a special issue of Religion, State and Society demonstrates (Martínez-Ariño, 2019). Though, little emphasis is placed on how the city's history and institutional path will direct choices in the management of religion as it diversifies and new issues arise. However, this idea has already been exploited in the sociology of migration to show how history and institutions will determine a city's attitude towards its migrants (Hackett, 2017; Schiller, 2012). We have seen from the history of Geneva that the path opened by the first settlements of religious diversity will determine the policies that will follow. Geneva, which was an entirely Protestant city-state, failed to recognize its new Catholic minority. This led to the separation of church and state, which only became more evident with the arrival of a new diversity at the end of the 20th century.

\section{Diversity in Geneva: The Bottom-Up Responses}

Faced with religious plurality, public authorities regulate the religious expressions in a top-down process. Another way of understanding the issues of recognition of religious groups in the city is to follow a bottom-up process. We will then show two bottom-up processes. The first is the interreligious initiatives, which are not insensitive to the city, since it allows the authority to regulate, softly, the diversity through the historical churches. The second one is a response to the constraints of normative background by the groups to obtain some legitimacy. In other words, how the groups adapt their activities to conform to the implicit expectation of the society.

Interreligious dialogue and initiatives are among the tools available for the city to 'domesticate' religious diversity:

The emergence and growth of interreligious initiatives can be understood through two complementary different theoretical perspectives, observes Griera: (a) as a consequence of a more general trend of religious de-privatization in contemporary societies; and (b) as a result of the increasing relevance of the governance of religious diversity and the implementation of 'technique of liberal governmentally' (Brown, 2006) aimed at regulating and domesticating religious groups. (Griera, 2020, p. 91) 
In Switzerland, one of the main NCS results was the dynamic of the interreligious initiative, an intermediate path between rejection and recognition of the religious groups (Stolz \& Monnot, 2017). The established Churches with legal or social recognition may co-opt newcomers and offer them at least a kind of social recognition. Newcomers are invited to participate in the interreligious dialogue or worship that the established churches lead. In Switzerland, NCS showed that 83.3\% of established Christian parishes have engaged in a joint ritual with another congregation. In roughly $70 \%$ of the cases, this other congregation was of a different religious tradition from theirs. In most cases, this common ritual was with another Christian congregation, in roughly $1 / 3$ of the cases with another nonestablished congregation.

In cities, this dialogue takes on social importance (Giordan \& Pace, 2014; Körs, 2018; Körs, Weisse, \& Willaime, 2020). The mayor and politicians generally participate in these interreligious gatherings, aiming to facilitate dialogue and a good understanding between religious groups. Interreligious dialogue allows communities to enter the "gray zone" (Becci \& Knobel, 2014) of the urban fabric, to be designated as reputable, while those who do not participate or are not invited to the interreligious dialogue are not. Those who are not invited remain invisible and are considered poorly integrated into urban society (Lamine, 2004).

The NCS has shown that the vast majority of local Christian communities participate at least once a year in ecumenical or interreligious worship (Monnot, 2013a, pp. 219-225; Stolz \& Monnot, 2017, pp. 82-84). However, this rate drops to less than one community in five among Christian minority communities, such as conservative Evangelicals (Darbysts or Bretheren). The rate is even lower among Jehovah's Witnesses or Mormons (Last-Day Saints). When the analysis is extended to nonChristian groups, the study reveals that $1 / 3$ of these local communities participate at least once a year in an interreligious celebration. This relatively high rate of cooptation in Switzerland from the established Churches to other 'acceptable' groups should not hide the fact that the invited groups belong to one of the major religious traditions (Islam, Buddhism, Hindu, Judaism, etc.), particularly their liberal wing (Stolz \& Monnot, 2017). This situation becomes even more significant when one observes that none of the groups of the holistic milieu in Switzerland participated in interreligious worship during the year of the survey.

In Geneva, on the initiative of pastors of the Protestant Church, a group for interreligious dialogue was set up in 1992. A few years later it formed an association under the name "Interreligious Platform of Geneva" (www.interreligieux.ch). One of the initiators, the Protestant pastor Basset, published a panorama with presentation sheets in alphabetical order of each religious community. Each card contains headings such as "Precepts of conduct," "Attitude of the community to- wards the State and society," a school card where one speaks, among other things, of the role and status of women and men in civil society as seen by the community in question, and finally a practical card with headings such as "Publications and Internet sites" (Basset, 2001). This platform organizes the 'week of religion' in November which is an opportunity for many groups to introduce themselves, take action, and invite other groups to pray with them. On this occasion, the platform distributes a booklet that presents itself in this way:

The Interreligious Platform of Geneva has been working for twenty-five years to promote recognition and dialogue between members of various religious traditions. Together, we are committed ourselves to ensuring that all people can live and practice their beliefs freely within the framework of the Swiss legal system. (Plateforme interreligieuse, 2017, p. 1)

This platform also published each year a rather successful interreligious calendar which on the calendar side indicates religious holidays and on the photo side presents images around a theme that changes every year. Obviously, this platform wants to present the religious diversity as valuable components of society. Differences, rites, and celebrations are ways of discovering other traditions and ways of making society. It also insists on the compatibility of religion with the legal system in force. It is a facade that presents religion as compatible with laicity, a necessary component of society for it to live in peace. As we can read in its booklet, it does not hide the fact that it is a means to obtain recognition (Plateforme interreligieuse, 2017).

However, this platform also plays a role in soft regulation of religion. As Gonzalez (2019) documents in a recent article, the city authorities asked the platform about a new Kosovar mosque that was being built in a neighborhood. All that was at stake was whether this mosque defended radical Islam or not. Gonzalez (2019) shows that this mosque has stirred up controversy in some religious positions, but that it has also been able to play the right score by being strongly committed to the interreligious platform, thus ensuring coverage to obtain the various establishment permits. The interreligious dialogue promoted by the established churches in Europe is not neutral (Beyer, 2020; Nagel, 2020). It is governed by implicit social norms that make a selection from within the diversity.

This involvement in interreligious meetings works, according to Lamine $(2005$, p. 83 ), as a "staging of interreligious understanding," where local religious groups appear together in the local public space to demonstrate their peaceful coexistence within the city alongside different religious communities and faiths. Our approach makes it possible to show how the established churches are (implicitly) invested with the role of 'regulation.' However, one can imagine other institutions in other fields operating in the same way. 
Not all religious communities can take part in interreligious dialogue. While Gonzalez's (2019) account of the history of the mosque sheds light on the role of legitimizing the activities of a local religious group in the eyes of society, many religious groups do not have access to this platform. This leads us to a second way of responding to the context of constraint by the communities in a bottomup process.

In her study "Snowboarding on Swiss Islam," Banfi (2013) conducted a survey of Muslim associations and organizations in Geneva and Zurich. She was interested in presenting the associative life and tried to understand the contribution of these different Muslim associations to civil society. She identified 30 areas in which these associations contributed, ranging from sport, to language learning, well-being, provision of typical products, and contact with other surrounding institutions. The important point to stress here is that these activities differ, of course, from one Muslim association to another. But if one compares the different activities of the associations in Geneva, there are no significant differences with Zurich. The few points of difference are mainly due to the profile of the Muslim populations. For example, Geneva has a higher proportion of people from the Maghreb speaking French, so learning the main language of the new city is not a priority compared to Zurich, where the population comes mainly from the former Yugoslavia and Turkey, areas where German is usually not spoken.

The point raised by Banfi (2013) was to show that these Muslim associations are therefore not only focused on prayer and the organization of religious services: They participate and are active in all kinds of activities in their neighborhoods and beyond. There was, however, a notable difference between the two cities with regard to the group's goals as set out in the association's statutes. In Zurich, the first goal mentioned is the prayer or the religious gathering, while in Geneva, this goal is never expressed to the detriment of others such as good integration, help for women, cultural center of a country of origin, etc. This difference sheds light on an important point about struggles for the recognition of religious actors. It is a question of adapting the strategy to integrate the association into the social fabric; two strategies for two different city contexts! In Zurich, the legal framework is favorable to religion. The church still has broad support for local policies. By declaring itself as a prayer room for a Muslim association, one is simply registering in an activity that is recognized in the city of Zurich, whereas in Geneva, as we have seen, the Church has lost its prerogatives and religion has no place in the public sphere. It is therefore in the interest of Muslim associations to profile themselves in some of the other activities offered by the group. By putting forward socio-cultural activities, they fulfill the expectations of a society which wants to see groups offering something other than religious practice. These associations therefore make their aim compatible with the constraints of a laïc republic. This adaptation in response to the constraints of social norms is another bottom-up way of struggling for recognition in an urban environment.

\section{Conclusion}

Following Hackett (2017), who suggested inserting the "local turn" of the study of migration in historical perspective in order to understand the different local governance between cities, we were able to identify the particular path of Geneva. The Protestant monopoly, even internally cracked with the fragmentation of Protestantism, did not bend politically in response to the claim for recognition by the large Catholic minority in the 19th century. The exclusion of the Catholic Church from the affairs of the city finally led to the adoption of a law of separation of Church and State. It can therefore be observed that Geneva has taken the path of separation. In the context of growing diversity, Geneva has continued on the path of separation and even accentuated this direction by declaring itself a laïc republic. This top-down process of governance reflects only part of the issues at stake in the recognition of religious communities in Geneva.

As suggested by Duemmler and Nagel (2013), it is also necessary to observe bottom-up processes in order to fully comprehend the strategies and claims of recognition from minority groups. Two processes have been described in Geneva. One is the interreligious, which plays an ambiguous role in selecting among the groups those that can be reputable and legitimizing those that participate. The case of the inauguration of a mosque in Geneva underlines the fact that the public authorities consult interreligious bodies before granting permission to open a new worship place. The second process is the profiling of the association according to the demands valued by the norms of the surrounding society. We have seen that in Geneva, Muslim associations are determined in their status like other secular associations by their social activities, whereas in Zurich, associations, which nevertheless propose very similar activities, can declare themselves as a mosque or prayer room in their status by the fact that the city of Zurich recognizes religious activity as an integral part of the social life of the city. In Geneva, the secular presentation of the activities of religious associations stems from the strict separation between Church and State, resulting from its religious history. For Zurich, its religious history is different and the governance of diversity has taken another path.

These two ways (top-down and bottom-up) of managing diversity are closely linked and respond to each other. Turning to the history of the city makes apparent the particular path that has been followed by the city's policies. It is by observing this path that one can perceive the different reasons for the struggle for recognition of religious groups. This path also provides a framework in which these communities will work to obtain the necessary legitimacy to ensure their success or simply their survival. Geneva's case highlights the fact that the city has become a laboratory where new ways of living to- 
gether in diversity have been shaped. However, in the context of super-diversity, with societal norms, laws, and levels of regulation, the question raised by the Geneva case is this: How will the path followed by the city produce innovations needed to deal with the increasingly fragmented diversity within the state regulation of religion framework?

\section{Acknowledgments}

We would like to thank Editage (www.editage.com) for English language editing.

\section{Conflict of Interests}

The author declares no conflict of interests.

\section{Supplementary Material}

Supplementary material for this article is available online in the format provided by the author (unedited).

\section{References}

Altermatt, U. (1994). Le catholicisme au défi de la modernité : L'histoire sociale des catholiques suisses aux $X I X e$ et XXe siècles [Catholicism facing the challenge of modernity: The social history of Swiss Catholics in the 19th and 20th centuries] (C. Giroud, Trans.). Lausanne: Payot.

Amsler, F., \& Scholl, S. (Eds.). (2013). L'apprentissage du pluralisme religieux: Le cas genevois au XIXe siècle [Coping with religious pluralism: The case of Geneva in the 19th century]. Geneva: Labor et Fides.

Banfi, E. (2013). Snowboarding on Swiss Islam. Neuchâtel: Alphil-Presses Universitaires Suisses.

Basset, J.-C. (Ed.). (2001). Panorama des religions: Traditions, convictions et pratiques [Overview of faiths: Traditions, beliefs and practices]. Geneva and Lausanne: Plateforme Interreligieuse and Enbiro.

Bastian, J.-P. (2016). La fracture religieuse Vaudoise 1847-1966: L'Eglise libre, "la Môme" et le canton de Vaud [The religious split in Canton of Vaud 1847-1966: The free church, the free faculty of theology, and the canton of Vaud]. Geneva: Labor et Fides.

Becci, I., Burchardt, M., \& Giorda, M. (2016). Religious super-diversity and spatial strategies in two European cities. Current Sociology, 65(1), 1-19. https:// doi.org/10.1177/0011392116632030

Becci, I., \& Hafner, J. (2016). Religious pluralization in Potsdam: A spatial perspective. Historia Religionum, 8, 97-108.

Becci, I., \& Knobel, B. (2014). La diversité religieuse en prison: Entre modèles de régulation et émergence de zones grises (Suisse, Italie et Allemagne) [Religious diversity in prisons: Between regulatory models and the emergence of grey zones (Switzerland, Italy and Germany)]. In A.-S. Lamine (Ed.), Quand le religieux fait conflit: Désaccords, négociations ou arrangements [When religion conflicts: Disagreements, negotiations or arrangements] (pp. 109-121). Rennes: Presses Universitaires de Rennes.

Berking, H., Steets, S., \& Schwenk, J. (2018). Religious pluralism and the city: Inquiries into postsecular urbanism. London: Bloomsbury Academic.

Beyer, P. (2020). Global migration, religious diversity and dialogue: Toward a post-westphalian circumstance. In A. Körs, W. Weisse, \& J.-P. Willaime (Eds.), Religious diversity and interreligious dialogue (pp. 27-42). Cham: Springer.

Burchardt, M., \& Becci, I. (2016). Religion and superdiversity: An introduction. New Diversities, 18(1), 1-7.

Burchardt, M., Becci, I., \& Giorda, M. (2018). Religious superdiversity and urban visibility in Barcelona and Turin. In H. Berking, S. Steets, \& J. Schwenk (Eds.), Religious pluralism and the city : Inquiries into postsecular urbanism (pp. 83-104). London: Bloomsbury Academic.

Caponio, T., \& Borkert, M. (2010). The local dimension of migration policymaking. Amsterdam: Amsterdam University Press.

Caponio, T., Scholten, P., \& Zapata-Barrero, R. (2019). The Routledge handbook of the governance of migration and diversity in cities. London and New York, NY: Routledge.

Duemmler, K., \& Nagel, A.-K. (2013). Governing religious diversity: Top-down and bottom-up initiatives in Germany and Switzerland. Integrative Psychological and Behavioral Science, 47(2), 265-283. https://doi.org/ 10.1007/s12124-012-9226-7

Giordan, G., \& Pace, E. (Eds.). (2014). Religious pluralism. Cham: Springer.

Glick Schiller, N., \& Caglar, A. (Eds.). (2010). Locating migration: Rescaling cities and migrants. Ithaca, NY: Cornell University Press.

Gonzalez, P. (2019). Inaugurer une mosquée à Genève: Médiatisation ambigüe, dialogue interreligieux et gestion du pluralisme [Inaugurating a mosque in Geneva: Ambiguous media coverage, interreligious dialogue and governance of pluralism]. In $\mathrm{M}$. Salzbrunn (Ed.), L'islam (in)visible en ville [Islam (in)visible in the city] (pp. 245-276). Geneva: Labor et Fides.

Grandjean, M., \& Scholl, S. (Eds.). (2010). L'Etat sans confession: La laïcité à Genève (1907) et dans les contextes suisse et français [The State without confession: Secularism in Geneva (1907) in the Swiss and French contexts]. Geneva: Labor et Fides.

Griera, M. (2020). Governing religious diversity through interreligious initiatives: Affinities, ambiguities and tensions. In A. Körs, W. Weisse, \& J.-P. Willaime (Eds.), Religious diversity and interreligious dialogue (pp. 89-102). Cham: Springer.

Hackett, S. E. (2017). The 'local turn' in historical perspective: Two city case studies in Britain and Germany. International Review of Administrative 
Sciences, 83(2), 340-357. https://doi.org/10.1177/ 0020852315592466

Heelas, P., \& Woodhead, L. (Eds.). (2005). The spiritual revolution: Why religion is giving way to spirituality. London: Blackwell.

Joppke, C., \& Seidle, F. L. (Eds.). (2012). Immigrant integration in federal countries. Montreal: McGillQueen's University Press.

Knobel, B., Gonzales, C., \& Montandon, J. (2014). D'église en ashram: Cartographie de la diversité religieuse à Genève [From Church to Ashram: Mapping religious diversity in Geneva]. Geneva: Centre Intercantonal d'Information sur les Croyances.

Körs, A. (2018). Congregations in Germany: Mapping of organizations, beliefs, activities, and relations: The case study of Hamburg. In C. Monnot \& J. Stolz (Eds.), Congregations in Europe (pp. 117-137). Cham: Springer.

Körs, A., Weisse, W., \& Willaime, J.-P. (Eds.). (2020). Religious diversity and interreligious dialogue. Cham: Springer.

Lamine, A.-S. (2004). Quand les villes font appel aux religions [When cities call upon religion]. Les Annales de la Recherche Urbaine, 96, 149-156.

Lamine, A.-S. (2005). Mise en scène de la "bonne entente" interreligieuse et reconnaissance [Staging of inter-religious "good relation" and recognition]. Archives de Sciences Sociales des Religions, 129, 83-96. Retrieved from http://assr.revues.org/1112

Martínez-Ariño, J. (2018a). Conceptualising the role of cities in the governance of religious diversity in Europe. Current Sociology, 66(5), 810-827. https://doi. org/10.1177/0011392117745942

Martínez-Ariño, J. (2018b). The evolution of religious diversity: Mapping religious minorities in Barcelona. In C. Monnot \& J. Stolz (Eds.), Congregations in Europe (pp. 177-193). Cham: Springer.

Martínez-Ariño, J. (2019). Governing religious diversity in cities: Critical perspectives. Religion, State and Society, 47(4/5), 364-373. https://doi.org/10.1080/ 09637494.2019 .1683404

Monnot, C. (2013a). Croire ensemble: Analyse institutionnelle du paysage religieux en Suisse [Believing together: Institutional Analysis of the Religious Landscape in Switzerland ]. Zurich: Seismo. Retrieved from http://archive-ouverte.unige.ch/unige:76531

Monnot, C. (Ed.). (2013b). La Suisse des mosquées: Derrière le voile de l'unité musulmane [The mosques in Switzerland: Behind the veil of Muslim unity]. Geneva: Labor et Fides.

Monnot, C., \& Stolz, J. (2020). The diversity of religious diversity: Using census and NCS Methodology in order to map and assess the religious diversity of a whole country. In A. Körs, W. Weisse, \& J.-P. Willaime (Eds.), Religious diversity and interreligious dialogue (pp. 133-151). Cham: Springer.

Monnot, C., \& Stolz, J. (Eds.). (2018). Congregations in Europe. Cham: Springer.
Morales Diez de Ulzurrun, L., \& Giugni, M. (2011). Social capital, political participation and migration in Europe: Making multicultural democracy work? New York, NY: Palgrave Macmillan.

Nagel, A.-K. (2020). Crossing the lines? Inter- and multifaith governance as an arena of boundary work. In A. Körs, W. Weisse, \& J.-P. Willaime (Eds.), Religious diversity and interreligious dialogue (pp. 103-116). Cham: Springer.

Plateforme Interreligieuse. (2017). For living together and respecting one another in a multi-religious society. Geneva: Plateforme interreligieuse.

Park, R. E., Burgess, E. W., \& Mackenzie, R. D. (1925). The city. Chicago, IL: University of Chicago Press.

Schiller, N. G. (2012). A comparative relative perspective on the relationships between migrants and cities. Urban Geography, 33(6), 879-903. https://doi.org/ 10.2747/0272-3638.33.6.879

Scholl, S. (2010). Contrôler ou séparer: Quel rôle pour l'etat en matière religieuse à Genève (1870-1880)? [Controlling or separating: What role for the state in religion regulation in Geneva (1870-1880)?]. In M. Grandjean \& S. Scholl (Eds.), L'etat sans confession: La laïcité à Genève (1907) et dans les contextes Suisse et Français [The State without confession: Secularism in Geneva (1907) in the Swiss and French contexts] (pp. 21-31). Geneva: Labor et Fides.

Scholl, S. (2013). Le Kulturkampf comme tentative d'intégration des catholiques à la nation: Le projet des catholiques libéraux genevois [The Kulturkampf as an attempt to Integrate Catholics into the Nation: The project of the Liberal Catholics of Geneva]. In F. Amsler \& S. Scholl (Eds.), L'apprentissage du pluralisme religieux: Le cas genevois au XIXe siècle [Coping with religious pluralism: The case of Geneva in the 19th Century] (Vol. 58, pp. 99-116). Geneva: Labor et Fides.

Stolz, J. (2018). Economics of religion on trial: How disestablishment did not lead to religious revival in the Swiss cantons of Geneva and Neuchâtel. Journal of Contemporary Religion, 33(2), 229-246. https://doi. org/10.1080/13537903.2018.1469263

Stolz, J., \& Chaves, M. (2017). Does disestablishment lead to religious vitality? The case of Switzerland. The British Journal of Sociology, 68, 412-435. https://doi. org/10.1111/1468-4446.12268

Stolz, J., Chaves, M., Monnot, C., \& Amiotte-Suchet, L. (2011). Die religiösen Gemeinschaften in der Schweiz: Eigenschaften, Aktivitäten, Entwicklung [The religious congregations in Switzerland: Characteristics, Activities, Development]. Bern: Swiss National Science Foundation. Retrieved from http:// www.pnr58.ch/files/downloads/Schlussbericht_ Stolz_Chaves.pdf

Stolz, J., Chaves, M., Monnot, C., Amiotte-Suchet, L, Bovey, F., Jossen, M. (2010). Enquête globale auprès des communautés religieuses en Suisse sur leur structure et leurs activités-2010 [Study on religious con- 
gregations in Switzerland: Structures and activities2010; Dataset]. https://doi.org/10.23662/FORS-DS656-1

Stolz, J., \& Monnot, C. (2017). The established and the newcomers: A Weberian-Bourdieusian view of congregations in the Swiss religious field. Revue d'Histoire et de Philosophie Religieuses, 97(1), 69-90.

Stringer, M. D. (2013). Discourses on religious diversity: Explorations in an urban ecology. Burlington, VT: Ashgate.

Vásquez, M. A., \& Knott, K. (2014). Three dimensions of religious place making in diaspora. Global Networks, 14(3), 326-347. https://doi.org/10.1111/glob.12062

Vertovec, S. (2007). Super-diversity and its implications. Ethnic and Racial Studies, 30(6), 1024-1054. doi:10.1080/01419870701599465

Wimmer, A., \& Glick Schiller, N. (2002). Methodological nationalism and beyond: Nation-state building, migration and the social sciences. Global Networks, 2(4), 301-334. https://doi.org/10.1111/1471-0374. 00043

\section{About the Author}

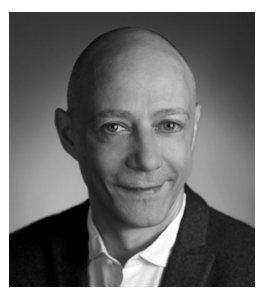

Christophe Monnot is Assistant Professor of Sociology of Religion at the University of Strasbourg and SNF Senior Researcher at the University of Lausanne. His research focuses on congregations in context. $\mathrm{He}$ is the author of many articles in leading journals like Social Compass (awarded in 2008 for the best article), Journal of Religions in Europe, and Journal of Contemporary Religions. He has edited several books in French and in English, such as Congregations in Europe (Springer, 2018, with J. Stolz). 